\title{
Korelasi Lingkar Pinggang dengan Kadar Gula Darah Puasa, Kadar Trigliserida, dan Tekanan Darah pada Mahasiswa Fakultas Kedokteran Universitas HKBP Nommensen
}

\author{
Rajagukguk, Y.A ${ }^{1}$, Sitanggang, E.J ${ }^{2}$, Saragih, R.A.C ${ }^{3}$, Simbolon, G.J ${ }^{4}$ \\ ${ }^{1}$ Fakultas Kedokteran Universitas HKBP Nommensen, Medan, Indonesia \\ ${ }^{2}$ Departemen Histologi Fakultas Kedokteran Universitas HKBP Nommensen, Medan, Indonesia \\ Email: ervinajulien@gmail.com \\ ${ }^{3}$ Departemen Ilmu Kesehatan Kulit dan Kelamin Fakultas Kedokteran Universitas HKBP Nommensen, Medan, \\ Indonesia \\ ${ }^{4}$ Laboratorium Penelitian Fakultas Kedokteran Universitas HKBP Nommensen, Medan, Indonesia
}

\begin{abstract}
Abstrak
Pendahuluan: Penyakit kardiovaskular adalah penyebab nomor satu kematian secara global dengan kejadian pada kelompok umur remaja dan dewasa muda di Indonesia sebanyak 153.705 kasus. Obesitas sentral berhubungan dengan risiko terjadinya penyakit kardiovaskular akibat peningkatan kadar gula darah puasa, kadar kolesterol, trigliserida dan tekanan darah. Tujuan penelitian: untuk mengetahui korelasi antara lingkar pinggang dengan kadar gula darah puasa, kadar trigliserida, dan tekanan darah pada orang dewasa muda. Metode: Penelitian analitik dengan pendekatan cross-sectional ini melibatkan 53 orang subjek usia dewasa muda (18-25 tahun). Lingkar pinggang diukur menggunakan pita meteran. Kadar gula darah dan trigliserida diukur dari sampel darah subjek penelitian setelah berpuasa 8-12 jam dengan mesin analyzer Cobas ${ }^{\circledR} 6000$. Data tekanan darah didapatkan dengan pengukuran menggunakan sfigmomanometer aneroid. Hasil: Pada penelitian ini didapatkan rerata lingkar pinggang subjek penelitian adalah 77,4 cm. Tidak ditemukan korelasi antara lingkar pinggang dengan kadar gula darah puasa $(\mathrm{p}=0,159)$. Namun, ditemukan korelasi positif antara lingkar pinggang dan kadar trigliserida $(\mathrm{p}=0,008 ; \mathrm{r}=0,332)$, antara lingkar pinggang dan tekanan darah sistolik $(\mathrm{p}=0,049 ; \mathrm{r}=0,230)$, dan antara lingkar pinggang dan tekanan darah diastolik $(\mathrm{p}=0,017 ; \mathrm{r}=0,293)$. Kesimpulan: lingkar pinggang berkorelasi positif dengan kadar trigliserida dan tekanan darah, tetapi tidak berkorelasi dengan kadar gula darah puasa.
\end{abstract}

Kata Kunci — Lingkar Pinggang, Kadar Gula Darah Puasa, Kadar Trigliserida, Tekanan Darah

\begin{abstract}
Introduction: Cardiovascular disease is the number one cause of death globally with an incidence of adolescents and young adults in Indonesia as many as 153.705 cases. Central obesity is associated with the risk of cardiovascular disease due to increase in fasting blood glucose levels, cholesterol and triglyceride levels, and blood pressure. Aims: to determine the correlation between waist circumference and fasting blood glucose levels, triglyceride levels, and blood pressure in young adults. Method: This analytic study with a crosssectional approach involved 53 young adult subjects (18-25 years old). Waist circumference is measured using a tape measure. Blood sugar and triglyceride levels were measured using Cobas ${ }^{\circledR} 6000$ analyzer machine from blood samples of subjects after fasting for 8-12 hours. Blood pressure data are obtained by measurement using aneroid sphygmomanometer. Results: In this study, the mean waist circumference of the research subjects was $77,4 \mathrm{~cm}$. No correlation was found between waist circumference and fasting blood sugar levels $(p=0,159)$. However, a positive correlation was found between waist circumference and triglyceride levels $(p=0,008 ; r=$ $0,332)$, between waist circumference and systolic blood pressure $(p=0,049 ; r=0,230)$, and between waist circumference and diastolic blood pressure ( $p=0,017 ; r=0,293)$. Conclusion: waist circumference is positively correlated with triglyceride levels and blood pressure, but does not correlate with fasting blood sugar levels.
\end{abstract}

Keywords - Waist Circumference, Fasting Blood Glucose Levels, Triglyceride Levels, Blood Pressure

Email : heme@unbrah.ac.id 


\section{Pendahuluan}

Penyakit kardiovaskular adalah sekelompok gangguan jantung dan pembuluh darah dan termasuk di dalamnya adalah penyakit serebrovaskular, penyakit jantung rematik, penyakit jantung koroner, dan kondisi lainnya. Penyakit kardiovaskular adalah penyebab nomor satu kematian secara global. Berdasarkan data World Health Organization (WHO) pada tahun 2016, diperkirakan sebesar 17,9 juta orang meninggal karena penyakit kardiovaskular, mewakili $31 \%$ dari kematian global. ${ }^{1}$

Pusat Data Informasi Kementerian Kesehatan RI menjelaskan bahwa ditemukan kejadian penyakit jantung koroner, gagal jantung dan stroke pada penduduk kelompok umur remaja dan dewasa muda (15-24 tahun) yaitu sebanyak $153.705 .^{2}$

Obesitas secara signifikan berhubungan dengan angka kematian yang lebih tinggi. ${ }^{3}$ Penelitian sebelumnya menunjukkan bahwa obesitas sentral (abdominal), yang ditentukan dengan pengukuran lingkar pinggang, memberikan informasi yang lebih akurat untuk memperkirakan morbiditas dan mortalitas dibandingkan obesitas umum yang ditentukan dengan indeks massa tubuh. Beberapa studi yang menghubungkan indeks massa tubuh dengan kejadian penyakit kardiovaskular melaporkan hasil yang tidak konsisten, di mana beberapa studi melaporkan adanya hubungan yang linear, sementara beberapa penelitian lain gagal menemukan adanya hubungan signifikan. ${ }^{4}$ Obesitas sentral dikaitkan dengan risiko komorbiditas seperti hipertensi dan diabetes. ${ }^{5}$ Risiko penyakit kardiovaskular meningkat dengan peningkatan kadar trigliserida. ${ }^{6}$ Lemak viseral dikaitkan dengan faktor risiko kardiovaskular melalui disfungsi endotel akibat resistensi insulin, gangguan lipolisis, dan peningkatan kadar asam lemak. $^{7}$ Lingkar pinggang diketahui berkorelasi dengan lemak abdominal total. ${ }^{8}$
Kelompok usia dewasa muda merupakan target yang penting untuk diberikan intervensi preventif atas masalah kesehatan seperti obesitas sentral. Penelitian ini bertujuan untuk mengetahui korelasi antara lingkar pinggang dengan kadar gula darah puasa, kadar trigliserida, dan tekanan darah pada kelompok usia dewasa muda.

\section{Metode Penelitian}

Penelitian ini adalah penelitian analitik dengan pendekatan cross-sectional. Populasi penelitian adalah mahasiswa aktif pada tahun akademik 2109-2020 Fakultas Kedokteran Universitas HKBP Nommensen. Sampel dipilih menggunakan teknik purposive sampling. Kriteria inklusi penelitian ini adalah mahasiswa berusia $\geq 18$ tahun dan bersedia mengikuti penelitian ini dengan menandatangani informed consent. Kriteria eksklusi penelitian ini adalah: mahasiswa yang sedang mengkonsumsi obat-obatan yang memengaruhi kadar gula darah, trigliserida, dan/atau tekanan darah, tidak dapat berdiri sendiri dengan baik (berdiri dengan bantuan orang lain atau alat), sedang menjalani program pengaturan pola makan tertentu, memiliki riwayat merokok 3 bulan terakhir atau sedang merokok, memiliki riwayat orang tua penderita diabetes atau hipertensi, dan sedang menjalani latihan fisik secara teratur.

Lingkar pinggang subjek diukur menggunakan pita meteran non-elastis. Kadar gula darah dan trigliserida diukur menggunakan mesin analisis kimia klinik merek Cobas® 6000 dari sampel darah subjek penelitian setelah berpuasa 8-12 jam. Tekanan darah diukur menggunakan sfigmomanometer aneroid. Protokol penelitian ini telah mendapatkan persetujuan layak etik dari Komisi Etik Penelitian Kesehatan Fakultas Kedokteran Universitas HKBP Nommensen.

Karakteristik subjek disajikan dalam rerata (simpang baku) atau median (nilai minimal - 
nilai maksimal) untuk data numerik dan dalam persentase untuk data kategorik. Obesitas sentral didefinisikan sebagai lingkar pinggang $>90 \mathrm{~cm}$ pada laki-laki dan $>80 \mathrm{~cm}$ pada perempuan. ${ }^{9}$ Kadar trigliserida diklasifikasikan berdasarkan panduan Adult Treatment Panel (ATP) III. ${ }^{10}$ Tekanan darah diklasifikasikan berdasarkan panduan hipertensi dari the Eight Joint National Committee (JNC 8). ${ }^{11}$ Data yang berdistribusi normal dianalisis menggunakan uji Pearson, sedangkan data yang tidak berdistribusi normal dianalisis dengan uji Spearman. Kemaknaan statistik ditentukan jika nilai $\mathrm{p}<0,05$. 1

\section{HASIL}

Penelitian dilakukan terhadap 53 orang mahasiswa berusia 18-25 tahun dengan proporsi $24,53 \%$ berjenis kelamin laki-laki dan $75,47 \%$ berjenis kelamin perempuan.

\section{A. Karakteristik Klinis SUbJeK Penelitian}

Pada tabel 1 dapat dilihat berdasarkan ukuran lingkar pinggangnya, subjek penelitian lebih banyak yang termasuk dalam kelompok tanpa obesitas sentral $(71,7 \%)$ dengan rerata lingkar pinggang subjek penelitian adalah 77,4 cm. Seluruh subjek pada penelitian ini memiliki kadar gula darah puasa $<100 \mathrm{mg} / \mathrm{dL}$, yang berarti seluruh subjek penelitian memiliki kadar gula darah puasa yang normal, ${ }^{12}$ dengan rerata 56,7 $\mathrm{mg} / \mathrm{dL}$. Mayoritas subjek penelitian memiliki kadar trigliserida yang normal $(88,7 \%)$ dengan rerata kadar trigliserida adalah 92,2 $\mathrm{mg} / \mathrm{dL}$. Mayoritas subjek penelitian memiliki tekanan darah sistolik dan diastolik yang normal dengan proporsi masing-masing $56,6 \%$ dan $71,7 \%$.
TABEL 1. KARAKTERISTIK KLINIS SUBYEK PENELITIAN

\begin{tabular}{ccc}
\hline Variabel & $\begin{array}{c}\mathbf{n} \\
(\boldsymbol{\%})\end{array}$ \\
\hline Lingkar pinggang $\mathbf{( c m )}$ & & $77,4 \pm 9,5^{*}$ \\
& & \\
Tanpa obesitas sentral & $38(71,7)$ & \\
Dengan obesitas sentral & $15(28,3)$ &
\end{tabular}

\section{Kadar gula darah puasa} $(\mathbf{m g} / \mathbf{d L})$

$\begin{array}{ll}39-44 & 5(9,4) \\ 45-50 & 11(20,8) \\ 51-56 & 9(17,0) \\ 57-62 & 14(26,4) \\ 63-68 & 4(7,5) \\ 69-73 & 10(18,9)\end{array}$

$\begin{array}{ll}\begin{array}{l}\text { Kadar trigliserida } \\ (\mathbf{m g} / \mathbf{d L})\end{array} & \\ \text { Normal } & 47(88,7) \\ \text { Borderline-Tinggi } & 4(7,5) \\ \text { Tinggi } & 2(3,8)\end{array}$

Tekanan darah sistolik (mmHg)

Normal

Prehipertensi

Tekanan darah diastolik (mmHg)

Normal

Prehipertensi Hipertensi derajat 1

*Rerata \pm Simpang Baku

${ }^{\text {\#}}$ Median (Minimal - Maksimal)

\section{B. Korelasi Lingkar Pinggang dengan Kadar Gula darah Puasa, KaDAR Trigliserida, DAN TEKanAN DARAH}

Hasil uji korelasi antara variabel lingkar pinggang dengan kadar gula darah puasa, kadar trigliserida, tekanan darah sistolik dan diastolik dapat dilihat pada Tabel 2.

Dari hasil uji statistik didapatkan bahwa terdapat korelasi positif dengan kekuatan korelasi yang lemah antara lingkar pinggang dengan kadar trigliserida, tekanan darah sistolik, dan tekanan darah diastolik. Namun, tidak terdapat korelasi antara lingkar pinggang dengan kadar gula darah puasa (Tabel 2). 
TABEL 2. KorElasi ANTARA LINGKAR PINGgANG DENGAN KADAR GULA DARAH PUASA, KADAR TRIGLISERIDA, TEKANAN DARAH SISTOLIK DAN DIASTOLIK

\begin{tabular}{ll}
\hline Variabel & Lingkar pinggang \\
\hline Kadar gula darah puasa* & $\mathrm{p}=0,159$ \\
& $\mathrm{r}=0,140$ \\
Kadar trigliserida* & $\mathrm{p}=0,008$ \\
& $\mathrm{r}=0,332$ \\
Tekanan darah sistolik & $\mathrm{p}=0,049$ \\
& $\mathrm{r}=0,230$ \\
Tekanan darah diastolik & $\mathrm{p}=0,017$ \\
& $\mathrm{r}=0,293$ \\
\hline
\end{tabular}

\section{Pembahasan}

\section{A. Karakteristik Klinis SubyeK Penelitian}

Obesitas sentral telah menjadi masalah kesehatan yang serius di negara-negara berkembang termasuk Indonesia. Obesitas sentral didefinisikan sebagai lingkar pinggang $>90 \mathrm{~cm}$ pada laki-laki dan $>80 \mathrm{~cm}$ pada perempuan standar Asia-Pasifik untuk obesitas sentral. ${ }^{9}$ Pada penelitian ini ditemukan bahwa angka kejadian obesitas sentral adalah 28,3\%. Angka tersebut mendekati prevalensi obesitas sentral pada populasi dewasa di Indonesia berdasarkan Survei Kesehatan Dasar Nasional tahun 2007, yaitu sebesar 28\%. Namun, angka tersebut jauh lebih rendah dibandingkan prevalensi obesitas sentral pada populasi dewasa di Amerika Serikat yang mencapai $55 \% .^{13}$ Prevalensi obesitas sentral pada dewasa muda di Indonesia yang cukup tinggi ini dapat disebabkan banyak hal seperti kondisi sosiodemografik ${ }^{14}$ (jenis kelamin, pekerjaan, tempat tinggal (kota/desa), pendapatan) dan gaya hidup (aktivitas fisik, sedentary lifestyle, pola konsumsi makanan). ${ }^{13}$

Penelitian sebelumnya menunjukkan keterkaitan obesitas dengan diabetes melitus tipe 2 melalui resistensi insulin. ${ }^{15}$ Menurut PERKENI, seseorang dikatakan menderita diabetes apabila kadar glukosa darah puasa $\geq$ $126 \mathrm{mg} / \mathrm{dL}$ dan pradiabetes apabila kadar glukosa darah puasa 100-126 mg/dL. Sementara itu, kadar glukosa darah puasa <
$100 \mathrm{mg} / \mathrm{dL}$ termasuk normal. ${ }^{16}$ Pada penelitian ini didapatkan hasil bahwa seluruh subjek penelitian memiliki kadar gula darah puasa yang normal, dengan rerata 56,7 $\mathrm{mg} / \mathrm{dL}$. Pada penelitian yang dilakukan Soewondo dan Pramono ditemukan bahwa insidensi pradiabetes/diabetes di Indonesia pada kelompok umur 18-27 tahun ditemukan relatif kecil, yaitu $6,5 \%$. Insidensi pradiabetes/diabetes meningkat seiring bertambahnya umur; yang paling besar adalah pada kelompok umur $\geq 58$ tahun $(31 \%){ }^{1{ }^{1}}$

Sampel penelitian ini mayoritas memiliki kadar trigliserida yang termasuk kategori normal. Hal yang sama juga ditemukan oleh Nurdamayanti dan Elon pada populasi dewasa berusia 26-45 tahun. $^{18}$ Kadar trigliserida berhubungan dengan usia di mana seiring bertambahnya usia kadar trigliserida cenderung meningkat. ${ }^{19}$ Pada penelitian ini subjek penelitian termasuk dalam kelompok usia dewasa muda sehingga metabolisme masih berjalan dengan baik yang menyebabkan keseimbangan kadar trigliserida dalam darah masih terjaga.

Tekanan darah sistolik mayoritas subjek penelitian berada dalam kategori normal. Akan tetapi, yang termasuk dalam kategori prehipertensi cukup banyak, yakni hampir separuh subjek penelitian. Penelitian pada mahasiswa fakultas kedokteran sebagai representasi kelompok usia dewasa muda telah dilakukan sebelumnya oleh Bawazier dkk pada tahun 2018 dan ditemukan bahwa terdapat kejadian prehipertensi yang cukup tinggi $(26,3 \%) .^{20}$

\section{B. Korelasi Lingkar Pinggang dengan Kadar Gula Darah Puasa, KadAR Trigliserida, DaN TekanaN DARAH}

Pada penelitian ini, dilakukan uji hipotesis untuk menentukan ada tidaknya korelasi antara lingkar pinggang dengan kadar gula darah puasa. Hasil uji hipotesis menunjukkan bahwa ukuran lingkar pinggang tidak 
memiliki korelasi dengan kadar gula darah puasa. Hasil penelitian ini sejalan dengan penelitian yang dilakukan oleh Putri pada mahasiswa dan mahasiswi Universitas Sanata Dharma Yogyakarta. $^{21}$ Hal ini mungkin disebabkan perbedaan antara massa lemak subkutan dan viseral dari subjek penelitian. Sebuah studi yang dilakukan Kwon dkk pada individu sehat menemukan bahwa massa lemak viseral memiliki korelasi yang lemah dengan kadar glukosa darah. Sementara itu, massa lemak subkutan ditemukan tidak memiliki korelasi dengan kadar glukosa darah. ${ }^{22}$ Perbedaan tersebut mungkin karena perbedaan aktivitas biologis antara jaringan lemak subkutan dan viseral.

Terdapat korelasi positif antara lingkar pinggang dengan kadar trigliserida dengan kekuatan korelasi yang lemah. Hasil penelitian ini sejalan dengan hasil penelitian yang telah dilaksanakan oleh Sari pada mahasiswa dan mahasiswi di Universitas Sanata Dharma Yogyakarta. ${ }^{23}$ Lemak viseral banyak terdapat dalam rongga perut yang dapat diketahui dari lingkar pinggang. Lemak ini memiliki adiposit yang berukuran besar yaitu adanya penimbunan jaringan lemak trigliserida yang menyebabkan peningkatan lipolisis dengan mudah, sehingga terjadi peningkatan asam lemak bebas. Peningkatan asam lemak bebas inilah yang dapat memicu hipertrigliseridemia. ${ }^{24}$

Pada penelitian ini juga didapatkan korelasi positif antara lingkar pinggang dengan tekanan darah sistolik dan diastolik. Hasil penelitian ini sejalan dengan penelitianpenelitian yang telah dilakukan sebelumnya pada mahasiswa. ${ }^{25,26}$. Hal ini mungkin diperantarai lemak viseral yang merupakan salah satu komponen massa lemak abdominal yang ditunjukkan oleh ukuran lingkar pinggang. Kelebihan lemak viseral akan meningkatkan tekanan darah sistolik dengan cara mengaktifkan sistem saraf simpatis dan dan sistem renin angiotensin. ${ }^{27}$

\section{KESIMPULAN DAN SARAN}

Pada penelitian ini didapatkan korelasi positif antara ukuran lingkar pinggang dengan kadar trigliserida dan tekanan darah, tetapi tidak terdapat korelasi antara lingkar pinggang dan kadar gula darah puasa pada mahasiswa Fakultas Kedokteran Universitas HKBP Nommensen. Oleh sebab itu, pada orang dewasa muda perlu diperhatikan ukuran lingkar pinggang, kadar trigliserida dan tekanan darah dengan rutin melakukan pemeriksaan kesehatan dan memulai mempraktikkan pola makan, minum, dan aktivitas yang sehat agar terhindar dari risiko penyakit kardiovaskular. Perlu dilakukan penelitian lebih lanjut yang lebih sensitif dalam menilai kondisi resistensi insulin pada obesitas sentral.

\section{Daftar Pustaka}

[1] World Health Organization. Cardiovascular Diseases [Internet]. [cited 2019 Oct 30]. Available from: https://www.who.int/healthtopics/cardiovascular-diseases/\#tab=tab_1

[2] Pusat Data dan Informasi Kementerian Kesehatan RI. Situasi Kesehatan Jantung. Kementerian Kesehatan RI. 2014.

[3] Yang HK, Han K, Kwon HS, Park YM, Cho JH, Yoon KH, et al. Obesity, metabolic health, and mortality in adults: A nationwide populationbased study in Korea. Sci Rep [Internet]. 2016;6(July):1-10. Available from: http://dx.doi.org/10.1038/srep30329

[4] Tchernof A, Després JP. Pathophysiology of human visceral obesity: An update. Physiol Rev. 2013;93(1):359-404.

[5] Harbuwono DS, Pramono LA, Yunir E, Subekti I. Obesity and central obesity in indonesia: Evidence from a national health survey. Med J Indones. 2018;27(2):53-9.

[6] Sone H, Tanaka S, Tanaka S, Iimuro S, Oida K, Yamasaki Y, et al. Serum level of triglycerides is a potent risk factor comparable to $\mathrm{LDL}$ cholesterol for coronary heart disease in Japanese patients with type 2 diabetes: Subanalysis of the Japan Diabetes Complications Study (JDCS). J Clin Endocrinol Metab. 2011;96(11):3448-56.

[7] Van Gaal LF, Mertens IL, De Block CE. Mechanisms linking obesity with cardiovascular disease. Nature. 2006;444(7121):875-80.

[8] Grundy SM, Neeland IJ, Turer AT, Vega GL. Waist circumference as measure of abdominal fat compartments. J Obes. 2013;2013. 
[9] World Health Organization. Waist Circumference and Waist-Hip Ratio Report of a WHO Expert Consultation [Internet]. World Health Organization. 2008. Available from: pps.who.int/iris/bitstream/handle/10665/44583/97 89241501491_eng.pdf?sequence=1

[10] Sweeney MET. What are the ATP III guidelines classification of triglycerides? [Internet]. 2019. Available

https://www.medscape.com/answers/126568 15893/what-are-the-atp-iii-guidelinesclassification-of-triglycerides

[11]Bell K, Twiggs J, Olin BR. Hypertension: The Silent Killer: Updated JNC8 Guideline Recommendations Associate Clinical Professor of Pharmacy Practice, Drug Information and Learning Resource Center. Alabama Pharm Assoc. 2015;1-8.

[12] Soelistijo SA, Novida H, Rudijanto A, Soewondo P, Suastika K MA. Konsensus Pengelolaan dan Pencegahan Diabetes Melitus Tipe 2 di Indonesia 2015.

[13] Kim D, Hou W, Wang F, Arcan C. Factors affecting obesity and waist circumference among US adults. Prev Chronic Dis. 2019;16(1):1-9.

[14] Mihardja L, Soetrisno U. Prevalence and Determinant Factors for Overweight and Obesity and Degenerative Diseases Among Young Adults in Indonesia. $\mathrm{J}$ ASEAN Fed Endocr Soc. 2012;27(1):77-81.

[15] Kriketos AD, Greenfield JR, Peake PW, Furler SM, Denyer GS, Charlesworth JA, et al. Inflammation, insulin resistance, and adiposity: A study of first-degree relatives of type 2 diabetic subjects. Diabetes Care. 2004;27(8):2033-40.

[16] Soelistijo SA, Novida H, Rudijanto A, Soewondo P, Suastika K, Manaf A. Konsensus Pengelolaan dan Pencegahan Diabetes Melitus Tipe 2 di Indonesia 2015. PERKENI; 2015. 1-58.

[17] Soewondo P, Pramono LA. Prevalence, characteristics, and predictors of pre-diabetes in Indonesia. Med J Indones. 2011;20(4):283-94.

[18] Nurdamayanti ME, Elon Y. Korelasi Indeks Massa Tubuh dengan Kadar Trigliserida. 2019;3(2):52-7.

[19] Miller M, Stone NJ, Ballantyne C, Bittner V, Criqui $\mathrm{MH}$, Ginsberg HN, et al. Triglycerides and cardiovascular disease: A scientific statement from the American Heart Association. Circulation. 2011;123(20):2292-333.

[20] Bawazier LA, Buntaran S, Sianipar W, Kekalih A. Blood Pressure Profile of Young Adults at the Faculty of Medicine Universitas Indonesia. Acta Med Indones. 2019;51(1):54-8.

[21] Putri AFC. Korelasi Lingkar Pinggang dan Rasio Lingkar Pinggang-Panggul Terhadap Kadar Glukosa Darah Puasa Pada Mahasiswa dan Mahasiswi Kampus III Universitas Sanata
Dharma Yogyakarta [skripsi]. Universitas Sanata Dharma Yogyakarta. 2013.

[22] Kwon HW, Lee SM, Lee JW, Oh JE, Lee SW, Kim SY. Association between volume and glucose metabolism of abdominal adipose tissue in healthy population. Obes Res Clin Pract [Internet]. 2017;11(5):133-43. Available from: http://dx.doi.org/10.1016/j.orcp.2016.12.007

[23] Sari DI. Korelasi Lingkar Pinggang dan Rasio Lingkar Pinggang Panggul terhadap Kadar Trigliserida Pada Mahasiswi dan Mahasiswa di Kampus III Universitas Sanata Dharma Yogyakarta [skripsi]. Universitas Sanata Dharma Yogyakarta. 2012.

[24]Eckel RH. The Metabolic Syndrome. In: Harrison's Principles of Internal Medicine. Eighteenth. United States: The McGraw-Hill Companies; 2012. p. 1994.

[25] Sumayku IM, Pandelaki K, Wongkar MCP. Hubungan Indeks Massa Tubuh Dan Lingkar Pinggang Dengan Tekanan Darah Pada Mahasiswa Fakultas Kedokteran Universitas Sam Ratulangi. e-CliniC. 2014;2(2).

[26] Setiawan AH, Hastuti J, Rahmawati NT. Hubungan Antara Lingkar Pinggang, Lingkar Perut dan Lingkar Lengan Atas dengan tekanan Darah Sistolik dan Diastolik pada Mahasiswa di Daerah Istimewa Yogyakarta [skripsi]. Universitas Gadjah Mada. 2015.

[27] White BA, Porterfield SP. Endocrine and Reproductive Physiology. 4th ed. Philadelphia: Elsevier; 2015. 71. 